\title{
Effects of cultivation and reforestation on suspended sediment concentrations: a case study in a mountainous catchment in China
}

\author{
N. F. Fang ${ }^{1,2}$, F. X. Chen ${ }^{3}$, H. Y. Zhang ${ }^{1,2}$, Y. X. Wang ${ }^{1,2}$, and Z. H. Shi ${ }^{2,3}$ \\ ${ }^{1}$ State Key Laboratory of Soil Erosion and Dryland Farming on the Loess Plateau, Northwest A \& F University, \\ Yangling 712100, People's Republic of China \\ ${ }^{2}$ Institute of Soil and Water Conservation of Chinese Academy of Sciences and Ministry of Water Resources, \\ Yangling 712100, People's Republic of China \\ ${ }^{3}$ College of Resources and Environment, Huazhong Agricultural University, Wuhan 430070, People's Republic of China
}

Correspondence to: Z. H. Shi (shizhihua70@gmail.com)

Received: 2 July 2015 - Published in Hydrol. Earth Syst. Sci. Discuss.: 7 August 2015

Revised: 30 November 2015 - Accepted: 20 December 2015 - Published: 15 January 2016

\begin{abstract}
Understanding how sediment concentrations vary with land use/cover is critical for evaluating the current and future impacts of human activities on river systems. This paper presents suspended sediment concentration (SSC) dynamics and the relationship between SSC and discharge $(Q)$ in the $8973 \mathrm{~km}^{2} \mathrm{Du}$ catchment and its sub-catchment $\left(4635 \mathrm{~km}^{2}\right)$. In the Du catchment and its sub-catchment, 4235 and 3980 paired SSC $-Q$ samples, respectively, were collected over 30 years. Under the influence of the Household Contract Responsibility System and Grain-for-Green projects in China, three periods were designated, the original period (1980s), cultivation period (1990s) and reforestation period (2000s). The results of a Mann-Kendall test showed that rainfall slightly increased during the study years; however, the annual discharge and sediment load significantly decreased. The annual suspended sediment yield of the Du catchment varied between $1.3 \times 10^{8}$ and $1.0 \times 10^{10} \mathrm{~kg}$, and that of the sub-catchment varied between $6.3 \times 10^{7}$ and $4.3 \times 10^{9} \mathrm{~kg}$. The SSCs in the catchment and subcatchment fluctuated between 1 and $22400 \mathrm{~g} \mathrm{~m}^{-3}$ and between 1 and $31800 \mathrm{~g} \mathrm{~m}^{-3}$, respectively. The mean SSC of the Du catchment was relatively stable during the three periods $\left( \pm 83 \mathrm{~g} \mathrm{~m}^{-3}\right)$. ANOVA (analysis of variance) indicated that the SSC did not significantly change under cultivation for low and moderate flows, but was significantly different under high flow during reforestation of the Du catchment. The SSC in the sub-catchment was more variable, and the mean SSC in the sub-catchment varied from
\end{abstract}

$1058 \pm 2217 \mathrm{~g} \mathrm{~m}^{-3}$ in the 1980 s to $1256 \pm 2496 \mathrm{~g} \mathrm{~m}^{-3}$ in the $1990 \mathrm{~s}$ and $891 \pm 1558 \mathrm{~g} \mathrm{~m}^{-3}$ in the 2000s. Reforestation significantly decreased the SSCs during low and moderate flows, whereas cultivation increased the SSCs during high flow. The sediment rating curves showed a stable relationship between the SSC and $Q$ in the Du catchment during the three periods. However, the SSC $-Q$ of the sub-catchment exhibited scattered relationships during the original and cultivation periods and a more linear relationship during the reforestation period.

\section{Introduction}

Suspended sediment is conventionally regarded as sediment that is transported by a fluid and is fine enough to remain suspended in turbulent eddies (Parsons et al., 2015). Suspended sediment plays important roles in the hydraulics, hydrology and ecology of rivers (Luo et al., 2013). Land use/cover is thought to affect hydrology and suspended sediment yield (SSY) (Van Rompaey et al., 2002; Casalí et al., 2010). Although many studies have assumed that forest cover is an effective method for controlling sediment yield throughout the world (e.g., Mount et al., 2005; Hopmans and Bren, 2007; Garzía-Ruiz et al., 2008; Stickler et al., 2009; Verbist et al., 2010; Lü et al., 2015; Wei et al., 2015), other studies have disagreed (e.g., Mizugaki et al., 2008; Ide et al., 2009). Ad- 
ditionally, many studies have implicated farmland as a major contributor of sediments (Gafur et al., 2003; Shi et al., 2004; Izaurralde et al., 2007; Cerdan et al., 2010). However, whether changes in land use/cover alter soil loss by changing the runoff volume or by changing the suspended sediment concentration (SSC) has received little attention. The relationships between SSC and discharge ( $Q$ have been discussed using sediment rating curves (Walling, 1977), a fuzzy logic model (Kisi et al., 2006), artificial neural networks (Liu et al., 2013) and other multivariate regression methods (Francke et al., 2008). SSCs are highly variable and can vary over many orders of magnitude during storm events (Naden and Cooper, 1999; Cooper, 2002; Fang et al., 2012). The mean annual/monthly SSC fails to capture the highly episodic nature of sediment transport because $>90 \%$ of the sediment load can be transported in $<10 \%$ of the time (Collins et al., 2011). Morehead et al. (2003) indicated that the suspended sediment load carried by rivers varies spatially and temporally and that sediment rating curve parameters can exhibit time-dependent trends. Warrick et al. (2013) concluded that the discharge and sediment relationships from six coastal rivers varied substantially with time in response to land use. In most studies, SSYs were calculated using SSCs and $Q$. However, little work has focused on the effects of land use/cover change on SSCs.

China contains $22 \%$ of the world's population but only $7 \%$ of the world's croplands (Liu and Diamond, 2005). In China, erosion by water affects an area of $3.6 \times 10^{6} \mathrm{~km}^{2}$, or approximately $37 \%$ of the country's land area (Ni et al., 2008). Thus, soil erosion has become an important topic for local and national policy makers. In the 1980s, a policy called the Household Contract Responsibility System was implemented in China's rural areas. Consequently, more land was reclaimed for farming. In the late 1999s, the Grain-for-Green project was introduced to increase forest and grassland cover. To combat soil erosion on sloped croplands, farmland with slopes $>25^{\circ}$ was restored. The farmers, who agreed to stop cultivating these lands received subsidies to cover their losses (Gao et al., 2012). Before this project, subtropical zones with adequate rainfall were often over-exploited due to economic and demographic pressures. Cultivation of steeply sloping lands in subtropical areas can result in serious soil erosion during intense rainfall (Fang et al., 2012). In this study, a mountainous catchment and its sub-catchment were investigated and analyzed in detail. This catchment is located in the Danjiangkou reservoir area, which is a source area in the Middle Route Project under the South-North Water Transfer Scheme (the largest water transfer project in the world). The study catchment has experienced cultivation and reforestation periods. The first part of this study focuses on how cultivation and reforestation affect $Q$, SSC and SSY at different timescales. Then, we discuss the dual roles of cultivation and reforestation that affect the relationship between SSC and $Q$. Finally, the SSC dynamics in the catchment and subcatchment were determined under land use/cover changes.

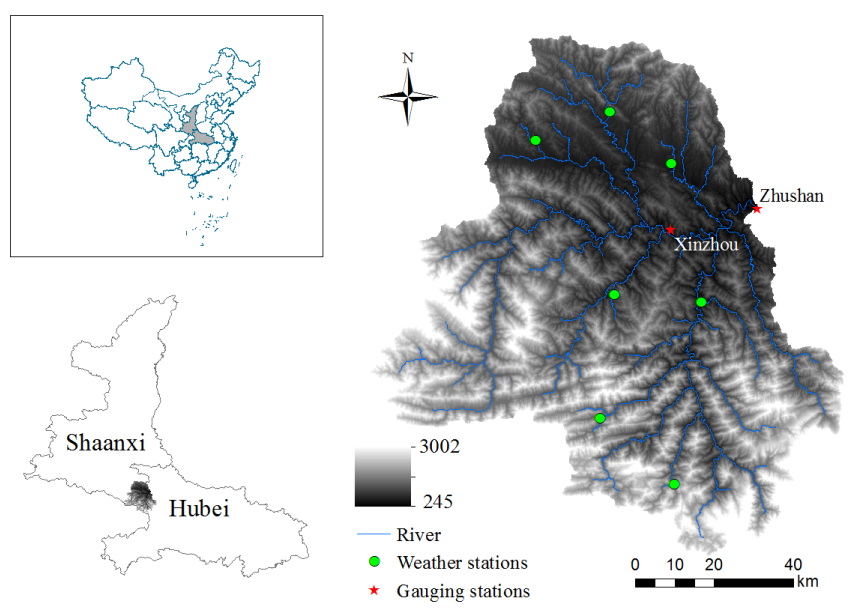

Figure 1. Location of study area.

\section{Study area and methods}

\subsection{Study area}

This study was conducted in the Du catchment $\left(31^{\circ} 30^{\prime}-\right.$ $32^{\circ} 37^{\prime} \mathrm{N}, 109^{\circ} 11^{\prime}-110^{\circ} 25^{\prime} \mathrm{E}$ ), which is located in Hubei Province, China, and covers an area of $8973 \mathrm{~km}^{2}$ (Fig. 1). Elevations within the watershed range from 245 to $3002 \mathrm{~m}$. The sub-catchment (Xinzhou catchment) is located in the northwest region of the Du catchment and covers an area of $4635 \mathrm{~km}^{2}$. The topography in the Du catchment is undulating and is characterized by mountain ranges, steep slopes and a subtropical climate with a mean temperature of $15^{\circ} \mathrm{C}$. The mean annual precipitation in this region is approximately $1000 \mathrm{~mm}$, with $80 \%$ of the precipitation occurring between May and September. The major soil types include yellow to brown soils, Chao soils and purple soils (National Soil Survey Office, 1992), which correspond to Alfisols, Entisols and Inceptisols, respectively, according to USDA Soil Taxonomy (Soil Survey Staff, 1999). The major crops in this region are corn (Zea mays L.) and wheat (Triticum aestivum L.). There were 1002 villages with total population of $1.9 \times 106$ based on the fifth population census of China in 2000.

\subsection{Land use/cover change}

The land cover was digitized as part of a previous research project. Reconnaissance field surveys were conducted in 2007. A watershed topographic map was used in combination with 1999 ETM (enhanced thematic mapper) photographs and Landsat imagery from 1987 and 2007. The land use/cover units were delineated on the photographs and verified in the field. We assigned the periods of the 1980s, 1990s, and 2000s to original, cultivation, and reforestation periods, respectively. The areas of the various types of land use/cover are presented in Tables 1 and 2. In 1987, forestland, farmland, and shrubland covered areas of $6316 \mathrm{~km}^{2}(70.4 \%)$, 
$919 \mathrm{~km}^{2}(10.2 \%)$ and $929 \mathrm{~km}^{2}(10.4 \%)$, respectively. The other land use/cover types covered small areas and included barren land $(0.4 \%)$, grassland $(7.3 \%)$, urban land $(0.9 \%)$, and water bodies $(0.4 \%)$ (Table 1$)$. During the 2000 s, some steep lands with slopes of more than $25^{\circ}$ were converted to forestland. The area of forestland increased to $75.2 \%$ in 2007, whereas the area of farmland decreased to $6.1 \%$ (Fig. 2). The sub-catchment experienced a similar change in farmland, which increased from $11.5 \%$ in 1987 to $14.7 \%$ in 1999 and decreased to $6.7 \%$ in 2007 . However, the change in forestland in the sub-catchment was different from that in the Du catchment, in which forestland increased from $66.3 \%$ in 1987 to $67.9 \%$ in 1999 and $74.0 \%$ in 2007 (Table 2).

\subsection{Data acquisition}

All of the hydrological data were obtained from the Hubei Provincial Water Resources Bureau. Two gauge stations (Zhushan and Xinzhou) and seven weather stations (nearly evenly distributed) are located in the study catchment. The yearly average rainfall measured at three weather stations in Xinzhou was very similar to the mean rainfall measured at the seven weather stations. Therefore, we used the average annual values of rainfall obtained from the seven stations for the Zhushan and Xinzhou stations. A continuously recording water-level stage recorder and a silt sampler (metal type) were used to record discharge and sediment (complemented by manual samples), respectively. The water stage was measured and transformed into discharge by using the calibrated rating curve obtained through periodic flow measurements. SSCs were determined using the gravimetric method, in which water samples were vacuum filtered through a $0.45 \mu \mathrm{m}$ filter and the residue was oven dried at $105^{\circ} \mathrm{C}$ for $24 \mathrm{~h}$. The weight of each dried residue and the initial sample volume were used to obtain the SSC $\left(\mathrm{g} \mathrm{m}^{-3}\right)$. Next, the SSY was calculated from the SSC and $Q$. During a month, the total SSY was the sum SSY of each event. Monthly SSC was calculated by monthly SSY and $Q$. During rainfall events, the sampling measurement frequency was increased several times each day. Paired SSC $-Q$ data were obtained during rainfallrunoff events. Because bed-load measurements were not performed in this area, this study does not consider bed-load sediment transport. From 1980 to 2009, 4235 paired SSC$Q$ samples were collected at the Zhushan station and 3980 samples were collected at the Xinzhou station. This study uses several variables, and their meanings and abbreviations are shown in Table 3. To distinguish between the variables of the two gauges, we used Qd, Dd, SSYd and SSCd for the Zhushan station (Du catchment) and Qx, Dx, SSYx and SSCx for the Xinzhou station (sub-catchment).
The variables for $D, \mathrm{SSY}_{i}$ and $\mathrm{SSY}$ are calculated as follows:

$D=Q / A$,

$\mathrm{SSY}_{i}=\mathrm{SSC}_{i} \times Q_{i}$,

$\mathrm{SSY}=\int_{1}^{n} \mathrm{SSY}_{i}$

where $A$ is the area of the catchment and $\mathrm{SSY}_{i}, \mathrm{SSC}_{i}$ and $Q_{i}$ are the suspended sediment yield, suspended sediment concentration and discharge during period $i$, respectively.

\subsection{Statistical analyses}

The Mann-Kendall test, which was proposed by Mann (1945) and Kendall (1975), was used to identify trends in $P, Q$ and SSY during the 30-year study period. The $S$ statistic was calculated as follows:

$S=\sum_{i=1}^{n-1} \sum_{j=i+1}^{n} \operatorname{sgn}\left(x_{j}-x_{i},\right)$

where $n$ is the number of data points, $x_{i}$ and $x_{j}$ are the respective data values in the time series $i$ and $j(j>1)$, and $\operatorname{sgn}\left(x_{j}-x_{i}\right)$ is the sign function (Gao et al., 2012), which is determined as follows:

$\operatorname{sgn}\left(x_{j}-x_{i}\right)=\left\{\begin{array}{c}+1, \text { if } x_{j}-x_{i}>0 \\ 0, \text { if } x_{j}-x_{i}=0 \\ -1, \text { if } x_{j}-x_{i}<0\end{array}\right.$.

The variance is computed as

$\operatorname{VAR}(S)$

$=\frac{1}{18}\left[n(n-1)(2 n+5)-\sum_{i=1}^{q} t_{i}\left(t_{i}-1\right)\left(2 t_{i}+5\right)\right]$,

where $n$ is the number of data points, $q$ is the number of tied groups and $t_{i}$ is the number of data values in the $i$ th group. The standard test statistic, $Z$, is computed as follows:

$Z=\left\{\begin{array}{l}\frac{S-1}{\sqrt{\operatorname{VAR}(S)}} \text { if } S>0 \\ 0 \quad \text { if } S=0 . \\ \frac{S+1}{\sqrt{\operatorname{VAR}(S)}} \text { if } S<0\end{array}\right.$.

A positive value of $Z$ indicates an upward trend, and a negative value of $Z$ indicates a downward trend. We use the threshold of \pm 1.96 for significant difference (Gao et al., 2012). The Mann-Kendall statistical test has frequently been used to quantify the significance of trends in hydrometeorological time series (Gocic and Trajkovic, 2013).

To discuss relationships between SSC and $Q$, hydrologists often use sediment rating curves. The most common 
Table 1. Land use/cover type and change ratio during 1978-2007 in the Du catchment

\begin{tabular}{lrrr|rrr}
\hline \multirow{2}{*}{ Land use/cover } & \multicolumn{3}{c|}{ Land use/cover $\left(\mathrm{km}^{2}\right)$ and ratio } & \multicolumn{2}{c}{ Land use/cover change $\left(\mathrm{km}^{2}\right)$ and change ratio } \\
\cline { 2 - 7 } & 1987 & 1999 & 2007 & $1999-1987$ & $2007-1999$ & $2007-1987$ \\
\cline { 2 - 7 } & $35(0.4 \%)$ & $26(0.3 \%)$ & $31(0.4 \%)$ & $-9(-0.1 \%)$ & $5(0.1 \%)$ & $-4(-0.0 \%)$ \\
Water & $81(0.9 \%)$ & $88(1.0 \%)$ & $115(1.3 \%)$ & $8(0.1 \%)$ & $26(0.3 \%)$ & $34(0.4 \%)$ \\
Urban land & $37(0.4 \%)$ & $38(0.4 \%)$ & $62(0.7 \%)$ & $1(0.0 \%)$ & $24(0.3 \%)$ & $26(0.3 \%)$ \\
Barren land & $6316(70.4 \%)$ & $6232(69.5 \%)$ & $6841(75.2 \%)$ & $-84(-0.9 \%)$ & $609(6.8 \%)$ & $525(5.9 \%)$ \\
Forest & $929(10.4 \%)$ & $846(9.4 \%)$ & $851(9.9 \%)$ & $-83(-0.9 \%)$ & $5(0.1 \%)$ & $-78(-0.9 \%)$ \\
Shrub & $657(7.3 \%)$ & $525(5.8 \%)$ & $551(6.4 \%)$ & $-132(-1.5 \%)$ & $26(0.3 \%)$ & $-106(-1.2 \%)$ \\
Grass & $919(10.2 \%)$ & $1218(13.6 \%)$ & $522(6.1 \%)$ & $299(3.3 \%)$ & $-695(-7.7 \%)$ & $-397(-4.4 \%)$ \\
Farmland & & & & &
\end{tabular}

Table 2. Land use/cover and change ratio during 1978-2007 in the Xinzhou catchment.

\begin{tabular}{lrrr|rrr}
\hline \multirow{2}{*}{ Land use/cover } & \multicolumn{2}{c|}{ Land use/cover $\left(\mathrm{km}^{2}\right)$ and ratio } & \multicolumn{3}{c}{ Land use/cover change $\left(\mathrm{km}^{2}\right)$} \\
\cline { 2 - 7 } & 1987 & 1999 & 2007 & $1999-1987$ & $2007-1999$ & $2007-1987$ \\
\hline Water & $16(0.3 \%)$ & $15(0.3 \%)$ & $14(0.3 \%)$ & $-1(0.0 \%)$ & $-1(0.0 \%)$ & $-2(0.0 \%)$ \\
Urban land & $52(1.1 \%)$ & $57(1.2 \%)$ & $51(1.1 \%)$ & $5(0.1 \%)$ & $-6(-0.1 \%)$ & $-1(0.0 \%)$ \\
Barren land & $20(0.4 \%)$ & $22(0.5 \%)$ & $41(0.9 \%)$ & $2(0.0 \%)$ & $19(0.4 \%)$ & $21(0.5 \%)$ \\
Forest & $3072(66.3 \%)$ & $3148(67.9 \%)$ & $3432(74.0 \%)$ & $76(1.6 \%)$ & $284(6.1 \%)$ & $360(7.8 \%)$ \\
Shrub & $537(11.6 \%)$ & $422(9.1 \%)$ & $479(10.3 \%)$ & $-115(-2.5 \%)$ & $57(1.2 \%)$ & $-58(-1.3 \%)$ \\
Grass & $404(8.7 \%)$ & $290(6.3 \%)$ & $307(6.6 \%)$ & $-114(-2.5 \%)$ & $17(0.4 \%)$ & $-97(-2.1 \%)$ \\
Farmland & $534(11.5 \%)$ & $679(14.7 \%)$ & $312(6.7 \%)$ & $145(3.1 \%)$ & $-367(-7.9 \%)$ & $-222(-4.8 \%)$ \\
\hline
\end{tabular}

Table 3. Variables and associated abbreviations used in the statistical analysis.

\begin{tabular}{lll}
\hline Abbreviations & Variables & Units \\
\hline$P$ & Rainfall & $\mathrm{mm}$ \\
$Q$ & Streamflow & $\mathrm{m}^{3} \mathrm{~s}^{-1}$ \\
$D$ & Discharge depth & $\mathrm{mm}$ \\
SSY & Suspended sediment yield & $\mathrm{kg} \mathrm{or} \mathrm{g} \mathrm{s}^{-1}$ \\
SSC & Suspended sediment concentration & $\mathrm{kg} \mathrm{m}^{-3} \mathrm{or} \mathrm{g} \mathrm{m}^{-3}$ \\
\hline
\end{tabular}

approach is to fit a power curve to the normal data (Khanchoul et al., 2008) as follows:

$\mathrm{SSC}=\alpha Q^{\beta}$

Here, $\alpha$ and $\beta$ are constants in the non-linear regression equation. The non-linear model assumes that the dependent variable (SSC) has a constant variance (scatter), which typically does not occur because the scatter around the regression generally increases with increasing $Q$ (Harrington and Harrington, 2013). The Mann-Kendall test was performed in MATLAB 7.0.

\section{Results}

\subsection{Streamflow and sediment yield during different periods}

Figure 3 shows the annual $P, D$ and SSY for the hydrological years of 1980-2009 from the Zhushan and Xinzhou gauges. The annual $P$ fluctuated between 665 and $1219 \mathrm{~mm}$. The annual Dd and Dx varied between 253 to $873 \mathrm{~mm}$ and 279 to $931 \mathrm{~mm}$, respectively. The annual SSY varied between $1.3 \times 10^{8}$ and $1.0 \times 10^{10} \mathrm{~kg} \mathrm{yr}^{-1}$ from the Zhushan gauge and between $6.3 \times 10^{7}$ and $4.3 \times 10^{9} \mathrm{~kg} \mathrm{yr}^{-1}$ from the Xinzhou gauge. To identify the relationships between the annual $P$, Dd, Dx, SSYd and SSYx, we generated a Pearson's correlation matrix, as shown in Fig. 4. The analysis showed significant correlations between all of the variables $(n=30$, $p<0.0001$ ). During the low-flow years (e.g., 1997 or 2001), SSYd was similar to SSYx. However, during the high-flow years (e.g., 1983 or 2005), SSYd was several times greater than SSYX.

The Mann-Kendall test was applied to the annual $P, D$ and SSY data for 1980-2009. The test shows a decreasing but not significant trend for $P$, a significant (5\% level) decreasing trend for $\mathrm{Qd}$, and highly significant decreasing trends for Qx, SSYx and SSYd (1\% level) (Fig. 5). After 2000, $P$ shows an increasing trend and $Q$ and SSY show decreasing trends. 

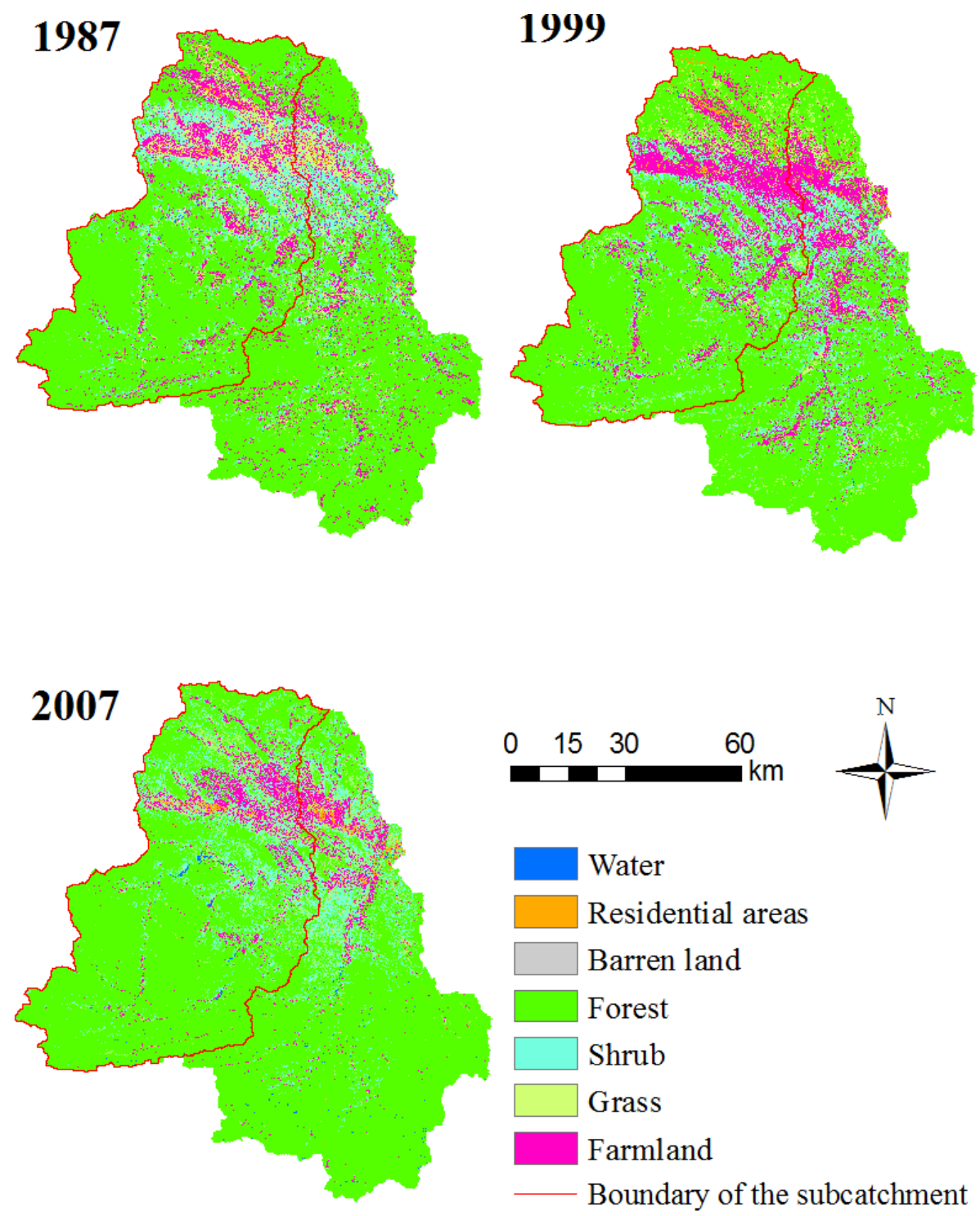

Figure 2. Land use changes during the three periods.

To better understand the dynamics of $Q$ and SSC, Tables 4 and 5 compare the observed average monthly $Q$ and SSC among the three periods monitored at the Zhushan and Xinzhou gauges.

During 1980s-1990s, the annual Qd showed a decreasing trend (Table 4), with only 3 of 12 months showing a slightly increasing trend. The rate of decrease varied from -3.3 to $-53.0 \%$. In addition, Qx exhibited a decreasing trend that was similar to that of Qd during the same period. During 1990s-2000s, Qd greatly increased from 1 to $34 \%$ during 9 of 12 months. Meanwhile, Qx increased over 8 months and fluctuated between $10 \%$ and $42 \%$. During 1990s-2000s, Qd and Qx both exhibited a more obvious increasing trend during the winter than during the flow seasons.
Table 5 shows the monthly mean SSC from the two gauges. SSCd decreased ( -1 to $-66 \%$ ) during the flow seasons (May to September), except in August, when it slightly increased (2\%) during 1980s-1990s. The decrease of SSCd did not coincide with that of Qd. During 1990s-2000s, the decrease in SSCd was more obvious than that in 1980s1990s. In all, 8 of 10 months experienced a decreasing change, and the change over 7 months was $>-40 \%$. In addition, the SSCx decreased over 6 months and increased during the other 4 months during 1980s-1990s. During 1990s2000s, the SSCx decreased over 7 months, and 4 out of 5 months showed a decreasing trend during the flow season. However, the monthly SSC is calculated by SSY and $Q$ and is not the actual SSC. To better understand SSC dynamics, 


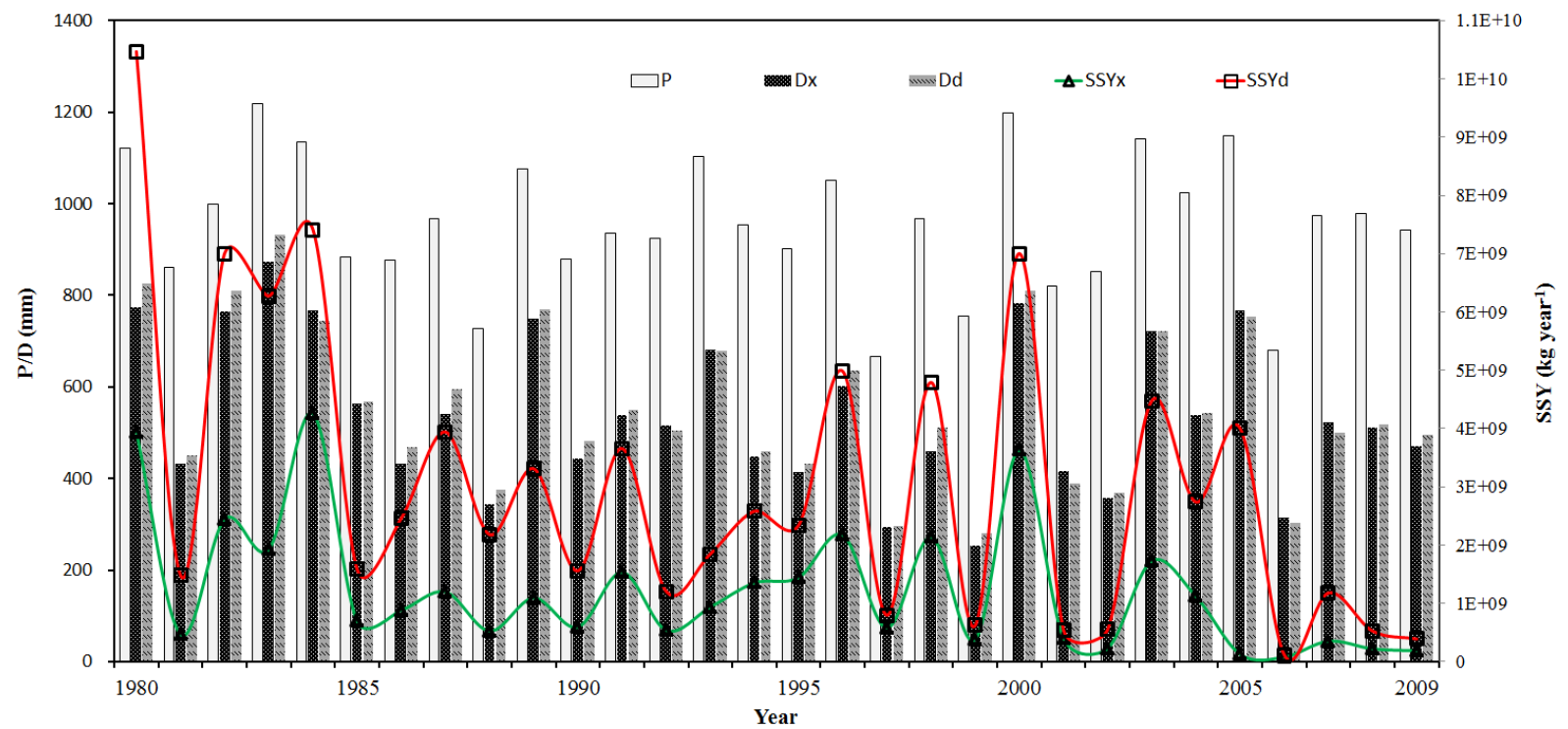

Figure 3. Annual $P, D$ and SSY for the hydrological years of 1980-2009 from the Zhushan and Xinzhou gauges.

Table 4. Monthly mean streamflow from the Xinzhou and Zhushan gauges.

\begin{tabular}{lrrr|rr|rrr|rr}
\hline & \multicolumn{3}{c}{$\left.\mathrm{Qd}^{3} \mathrm{~m}^{3} \mathrm{~s}^{-1}\right)$} & \multicolumn{2}{c|}{ Change $(100 \%)$} & \multicolumn{2}{c|}{ Qx $\left(\mathrm{m}^{3} \mathrm{~s}^{-1}\right)$} & \multicolumn{2}{c}{ Change (100\%) } \\
\cline { 2 - 10 } & $1980 \mathrm{~s}$ & $1990 \mathrm{~s}$ & $2000 \mathrm{~s}$ & $\mathrm{C} 1$ & $\mathrm{C} 2$ & $1980 \mathrm{~s}$ & $1990 \mathrm{~s}$ & $2000 \mathrm{~s}$ & $\mathrm{C} 1$ & $\mathrm{C} 2$ \\
\hline Jan & 35 & 33 & 41 & $-5.7 \%$ & $24.2 \%$ & 17 & 13 & 19 & $-23.5 \%$ & $46.2 \%$ \\
Feb & 37 & 46 & 49 & $24.3 \%$ & $6.5 \%$ & 18 & 19 & 21 & $5.6 \%$ & $10.5 \%$ \\
Mar & 85 & 96 & 74 & $12.9 \%$ & $-22.9 \%$ & 42 & 46 & 31 & $9.5 \%$ & $-32.6 \%$ \\
Apr & 186 & 146 & 160 & $-21.5 \%$ & $9.6 \%$ & 92 & 72 & 61 & $-21.7 \%$ & $-15.3 \%$ \\
May & 185 & 200 & 203 & $8.1 \%$ & $1.5 \%$ & 89 & 97 & 89 & $9.0 \%$ & $-8.2 \%$ \\
Jun & 274 & 224 & 192 & $-18.2 \%$ & $-14.3 \%$ & 132 & 115 & 111 & $-12.9 \%$ & $-3.5 \%$ \\
Jul & 412 & 223 & 262 & $-45.9 \%$ & $17.5 \%$ & 207 & 119 & 173 & $-42.5 \%$ & $45.4 \%$ \\
Aug & 269 & 260 & 257 & $-3.3 \%$ & $-1.2 \%$ & 129 & 136 & 156 & $5.4 \%$ & $14.7 \%$ \\
Sep & 338 & 159 & 202 & $-53.0 \%$ & $27.0 \%$ & 173 & 76 & 109 & $-56.1 \%$ & $43.4 \%$ \\
Oct & 255 & 136 & 155 & $-46.7 \%$ & $14.0 \%$ & 123 & 67 & 103 & $-45.5 \%$ & $53.7 \%$ \\
Dec & 121 & 94 & 95 & $-22.3 \%$ & $1.1 \%$ & 57 & 42 & 47 & $-26.3 \%$ & $11.9 \%$ \\
Nov & 49 & 41 & 62 & $-16.3 \%$ & $51.2 \%$ & 23 & 18 & 30 & $-21.7 \%$ & $66.7 \%$ \\
\hline Average & 187 & 138 & 146 & $-26.2 \%$ & $5.8 \%$ & 92 & 68 & 79 & $-26.1 \%$ & $16.2 \%$ \\
\hline
\end{tabular}

Note: $\mathrm{C} 1$ is the change for 1990-1980; C2 is the change for 2000-1990.

paired SSC $-Q$ data collected by monitoring should be discussed.

\subsection{SSC $-Q$ dynamics}

Figure 6 shows the statistical characteristics of the SSC and $Q$ during the three periods. The mean SSCd was relatively stable during the three periods $\left( \pm 83 \mathrm{~g} \mathrm{~m}^{-3}\right)$, and the mean SSCx varied from $1058 \mathrm{~g} \mathrm{~m}^{-3}$ in the $1980 \mathrm{~s}$ to $1256 \mathrm{~g} \mathrm{~m}^{-3}$ in the 1990s and then decreased to $891 \mathrm{~g} \mathrm{~m}^{-3}$ in the 2000s. In the 1980s, the max SSCd and max SSCx were 22400 and $31800 \mathrm{~g} \mathrm{~m}^{-3}$, respectively. Next, the max SSCd shape decreased to $20000 \mathrm{~g} \mathrm{~m}^{-3}$ during the $1990 \mathrm{~s}$ and to $17800 \mathrm{~g} \mathrm{~m}^{-3}$ during the 2000s. Meanwhile, the max SSCx decreased to 26900 and $19200 \mathrm{~g} \mathrm{~m}^{-3}$ during the 1990s and 2000s, respectively. The max Qx was more variable than the max Qd and was $12400 \mathrm{~g} \mathrm{~m}^{-3}$ in the $1980 \mathrm{~s}, 3610 \mathrm{~g} \mathrm{~m}^{-3}$ in the $1990 \mathrm{~s}$ and $3010 \mathrm{~g} \mathrm{~m}^{-3}$ in the 2000s. However, the rate of change of the mean Qx was similar to that of the mean Qd.

Figure 7 shows that the SSCs varied by several orders of magnitude for a given discharge at both gauges. SSCd and SSCx fluctuated between 1 and $22400 \mathrm{~g} \mathrm{~m}^{-3}$ and between 1 and $31800 \mathrm{~g} \mathrm{~m}^{-3}$, respectively. The maximum SSCx $\left(31800 \mathrm{~g} \mathrm{~m}^{-3}\right)$ was larger than the maximum SSCd $\left(21400 \mathrm{~g} \mathrm{~m}^{-3}\right)$. In Fig. 7, SSCd-Qd maintained a stable relationship during the three periods (1980s, 1990s and 
Table 5. Monthly mean suspended sediment concentration from the Xinzhou and Zhushan gauges.

\begin{tabular}{lrrr|rr|rrr|rr}
\hline & \multicolumn{3}{c}{$\mathrm{SSCd}\left(\mathrm{g} \mathrm{m}^{-3}\right)$} & \multicolumn{2}{c|}{ Change $(100 \%)$} & \multicolumn{2}{c|}{$\mathrm{SSCx}\left(\mathrm{g} \mathrm{m}^{-3}\right)$} & \multicolumn{2}{c}{ Change $(100 \%)$} \\
\cline { 2 - 10 } & $1980 \mathrm{~s}$ & $1990 \mathrm{~s}$ & $2000 \mathrm{~s}$ & $\mathrm{C} 1$ & $\mathrm{C} 2$ & $1980 \mathrm{~s}$ & $1990 \mathrm{~s}$ & $2000 \mathrm{~s}$ & $\mathrm{C} 1$ & $\mathrm{C} 2$ \\
\hline Jan & 0 & 0 & 0 & - & - & 0 & 0 & 0 & - & - \\
Feb & 10 & 1 & 2 & $-90 \%$ & $100 \%$ & 3 & 0 & 0 & $-100 \%$ & - \\
Mar & 7 & 15 & 1 & $114 \%$ & $-93 \%$ & 3 & 12 & 1 & $300 \%$ & $-92 \%$ \\
Apr & 224 & 147 & 56 & $-34 \%$ & $-62 \%$ & 118 & 81 & 28 & $-31 \%$ & $-65 \%$ \\
May & 427 & 256 & 139 & $-40 \%$ & $-46 \%$ & 298 & 128 & 127 & $-57 \%$ & $-1 \%$ \\
Jun & 629 & 623 & 321 & $-1 \%$ & $-48 \%$ & 471 & 718 & 430 & $52 \%$ & $-40 \%$ \\
Jul & 122 & 755 & 686 & $-38 \%$ & $-9 \%$ & 929 & 895 & 603 & $-4 \%$ & $-33 \%$ \\
Aug & 942 & 963 & 364 & $2 \%$ & $-62 \%$ & 736 & 961 & 411 & $31 \%$ & $-57 \%$ \\
Sep & 674 & 229 & 239 & $-66 \%$ & $4 \%$ & 409 & 115 & 186 & $-72 \%$ & $62 \%$ \\
Oct & 268 & 146 & 46 & $-46 \%$ & $-68 \%$ & 185 & 84 & 84 & $-55 \%$ & $0 \%$ \\
Dec & 26 & 86 & 1 & $231 \%$ & $-99 \%$ & 18 & 54 & 1 & $200 \%$ & $-98 \%$ \\
Nov & 0 & 0 & 0 & - & - & 0 & 0 & 0 & - & - \\
Average & 369 & 268 & 155 & $-27.4 \%$ & $-42.1 \%$ & 264 & 254 & 156 & $-3.8 \%$ & $-38.6 \%$ \\
\hline
\end{tabular}

Note: $\mathrm{C} 1$ is the change for 1990s-1980s; C2 is the change for 2000s-1990s. Suspended sediment primarily loads during the flow season. Rainfall is rare in the winter (Dec, Nov and Jan), and the streamflow is dominated by a base flow; thus, in most years, there is no suspended sediment load.

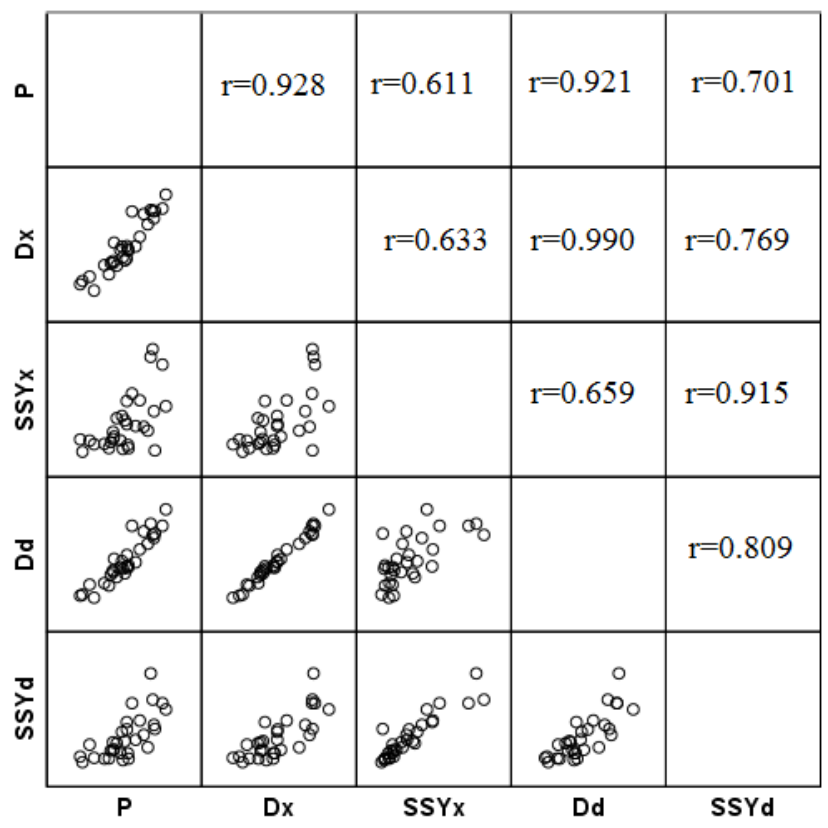

Figure 4. Bivariate scatter-plot matrix of selected variables.

2000s). However, SSCx-Qx showed a scattered relationship from 1980s and 1990s and showed a more liner relationship from 2000s. During the three periods, the max Qd decreased from 9880 to 6140 and $5070 \mathrm{~m}^{-3} \mathrm{~s}^{-1}$, respectively. Meanwhile, the max Qx was reduced from 5960 to 3580 and $2990 \mathrm{~m}^{-3} \mathrm{~s}^{-1}$, respectively.

The relationship between SSC and $Q$ is complicated. To better understand the dynamics of SSC, SSC was sorted by ranking the paired $Q$ values, which were classified using a threshold level approach (e.g., low flow ( $Q \leq 25 \%)$,

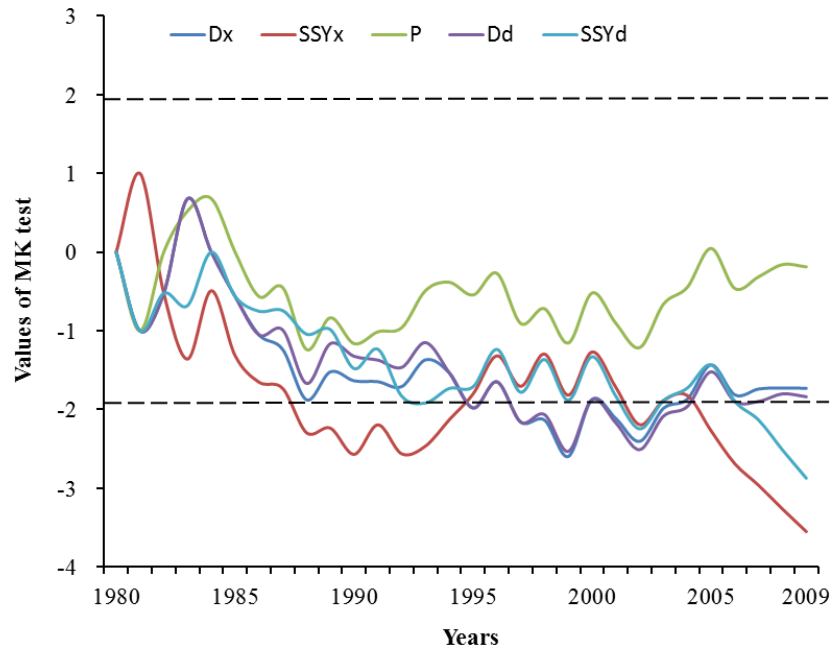

Figure 5. Results of the Mann-Kendall test.

moderate flow $(25<Q<75 \%)$, and high flow $(Q \geq 75 \%)$. The SSC dynamics were compared under different flow regimes. For the sub-catchment, the thresholds were 188 and $674 \mathrm{~m}^{3} \mathrm{~s}^{-1}$ for the minimum $25 \%$ and maximum $25 \%$, respectively. For Qd, the thresholds of the minimum and maximum $25 \%$ were 332 and $1100 \mathrm{~m}^{3} \mathrm{~s}^{-1}$, respectively. Figure 8 presents box plots for SSCd and SSCx during the three periods for the three flow grades. The box plots indicate the maximum, 75,50 and $25 \%$, and minimum values for each SSC (outliers are excluded). For the sub-catchment, SSCx increased between the original period and the cultivation period for moderate and high flow, but not for low flow. Then, SSCx decreased during the reforestation period for all flows. At the Zhushan station, SSCd was larger during the cultivation period for both moderate and high flows. During the 

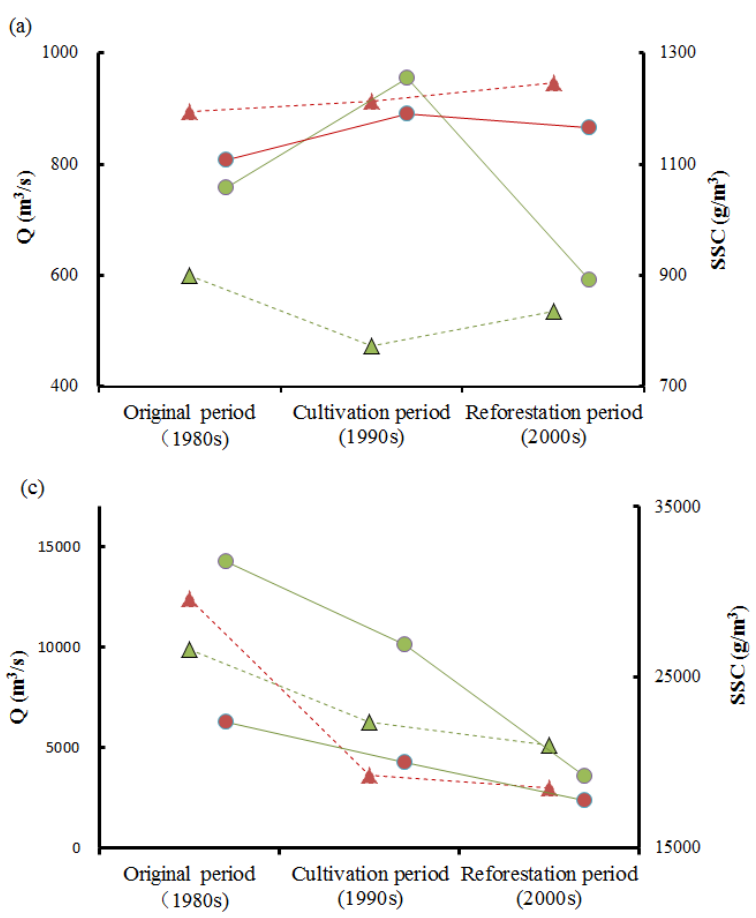
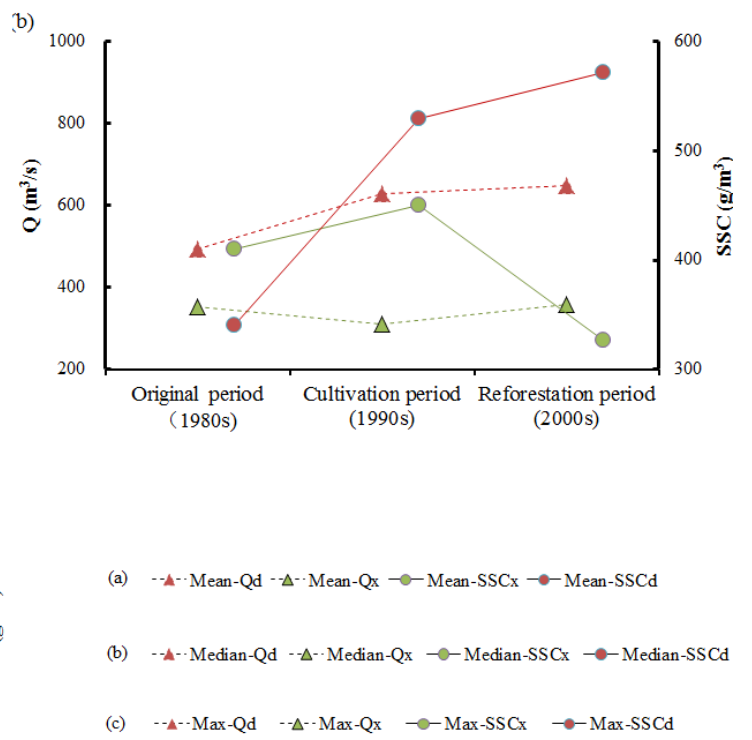

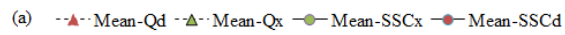

(c) $\quad-\Delta^{-}-$Max-Qd $\quad-\Delta^{-}-$Max $-\mathrm{Qx} \quad \longrightarrow-$ Max-SSCx $\quad-\bullet-$ Max-SSCd

Figure 6. Descriptive statistics of $Q$ and SSC.

reforestation period, the SSCd during low flow was higher than during the other periods.

Six ANOVA tests were performed using SSC as the dependent variable and using the different periods (land use) as independent variables. ANOVA was only conducted for the same flow during different periods. One-way ANOVA (Table 6) revealed that SSCx showed significant differences among the different periods for all three types of flows $(p<0.001)$. However, a significant difference in SSCd was only observed among high flows $(p<0.001)$. No statistically significant differences were observed among the SSCd values during the different periods for low or moderate flows.

\section{Discussion}

Land use/cover has been widely documented to have dire environmental consequences through their adverse impacts on soil and water qualities (Zhang et al., 2015). Olang et al. (2014) indicated that $40 \%$ and 51 of forest and agriculture land revealed reduced runoff volumes by about $12 \%$, while $86 \%$ land cover of agriculture increased runoff volumes by about $12 \%$. Buendia et al. (2015) studied the effects of afforestation on runoff at a Pyrenean Basin $\left(2807 \mathrm{~km}^{2}\right)$, and the results showed that an increase ranging between $19 \%$ and $57 \%$ in the forest of sub-basins accounted for $\sim 40 \%$ of the observed decrease in annual runoff. Liu et al. (2014) demonstrated that afforestation leads to increased runoff in dry seasons in the Yarlung Zangbo River basin. In this study, land use/cover changes significantly affect $Q$ and SSY (Ta- bles 4 and 5). During the cultivation period, an increase in farmland resulted in an obvious decreasing trend in $Q$ in the Du catchment and its sub-catchment. The sediment concentration in the direct runoff from a slope consists of a combination of the sediment stored on the slope and that generated by flow erosion during the current rainfall event (Aksoy and Kavvas, 2005; Rankinen et al., 2010). Large storms generate sufficient surface runoff to deliver sediment from the uplands to the stream. In forest catchments overflow typically occurs only in a small fraction of the catchment, and it is most likely to occur very close to the stream (Underwood et al., 2015). Reforestation may increased the return period of peak flow and peak sediment yield (Keesstra, 2007). Borrelli et al. (2015) illustrated that a disturbed forest sector could produce about $74 \%$ more net erosion than a 9 times larger, undisturbed forest sector. High SSCs are not detected in the absence of a high-flow velocity to carry the suspended sediment to the outlet of a catchment. SSCs are determined by onsite sediment production and the connectivity of sediment sources to the channel. Sediment delivered to the channel can be deposited (Keesstra et al., 2009). When runoff is decreased, its erodibility is reduced (Bakker et al., 2008; Van Rompaey et al., 2002). Reduced streamflow can reduce the sediment transport capacity and increase the probability for further sediment deposition in the river (Zhu et al., 2015). Human-induced modifications of land use/cover in river basins may cause strong geomorphic responses by disturbing sediment supply, transport and deposition processes (Liébault et al., 2005). 

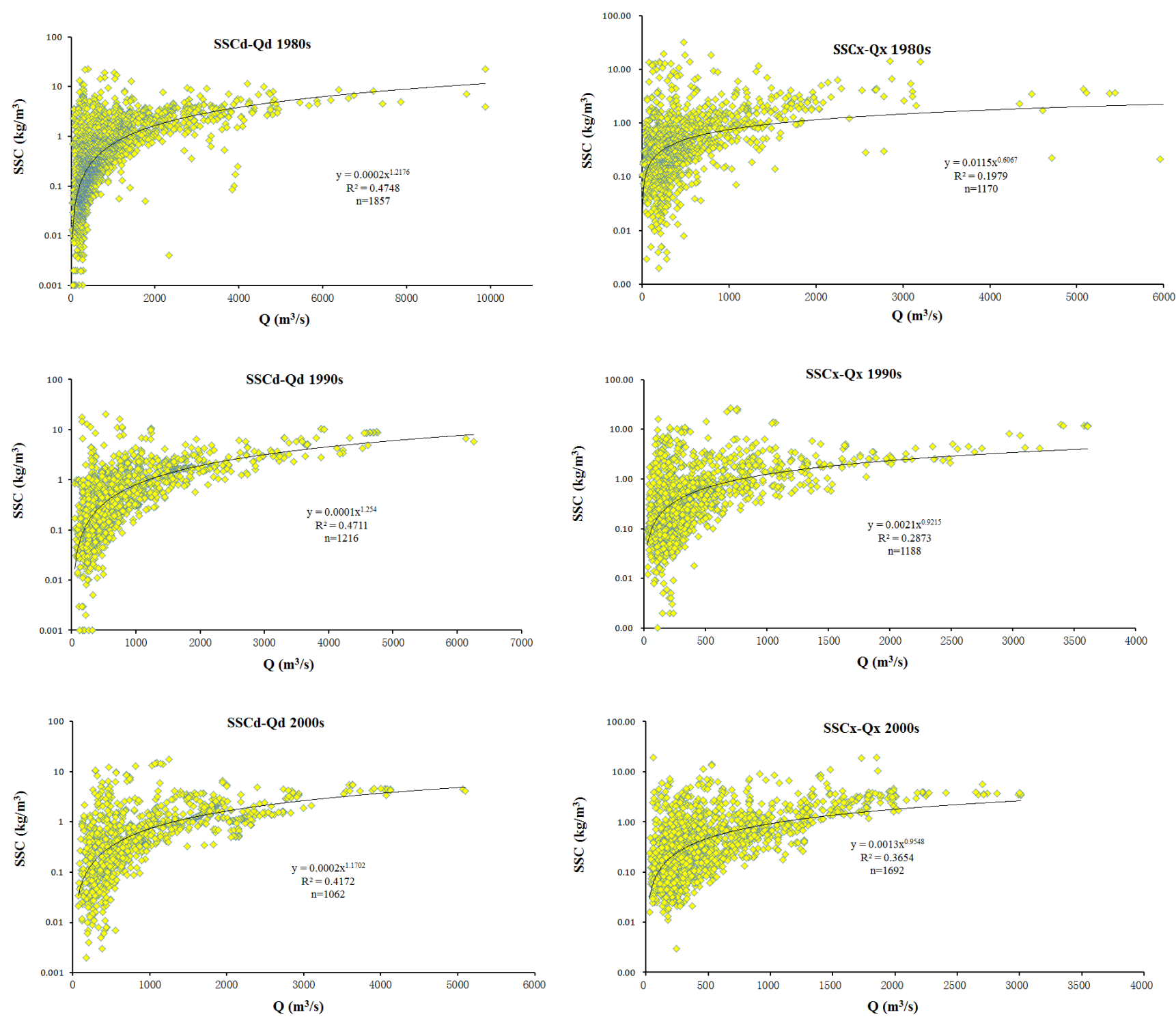

Figure 7. SSC $-Q$ relationships during the three periods for the two gauges.

Table 6. Mean SSC values and one-way ANOVA of SSCs during the different periods.

\begin{tabular}{llrrrr}
\hline & & Original & Cultivation & Reforestation & $p$ value \\
\hline \multirow{2}{*}{ Mean SSCd $\left(\mathrm{g} \mathrm{m}^{-3}\right)$} & Low flow & 0.49 & 0.50 & 0.44 & 0.285 \\
& Moderate flow & 0.83 & 0.86 & 0.97 & 0.080 \\
& High flow & 2.42 & 2.43 & $2.02^{*}$ & 0.002 \\
Mean SSCx $\left(\mathrm{g} \mathrm{m}^{-3}\right)$ & Low flow & 0.68 & 0.66 & $0.36^{*}$ & 0.000 \\
& Moderate flow & 0.87 & 0.97 & $0.64^{*}$ & 0.000 \\
& High flow & 1.80 & $2.83^{*}$ & 1.80 & 0.000 \\
\hline
\end{tabular}

Note: ANOVA was only conducted for the same flow during different periods; ${ }^{*}$ means significant difference at $\alpha=0.05$.

Hydrological studies rely on the analysis of processes at different spatial scales (García-Ruiz et al., 2008). Sediment yield and watershed areas have been elucidated in many stud- ies (e.g., Renschler and Harbor, 2002; de Vente and Poesen, 2013). The mean SSC was stable during the study years in the Du catchment, and the mean SSC varied in the sub- 

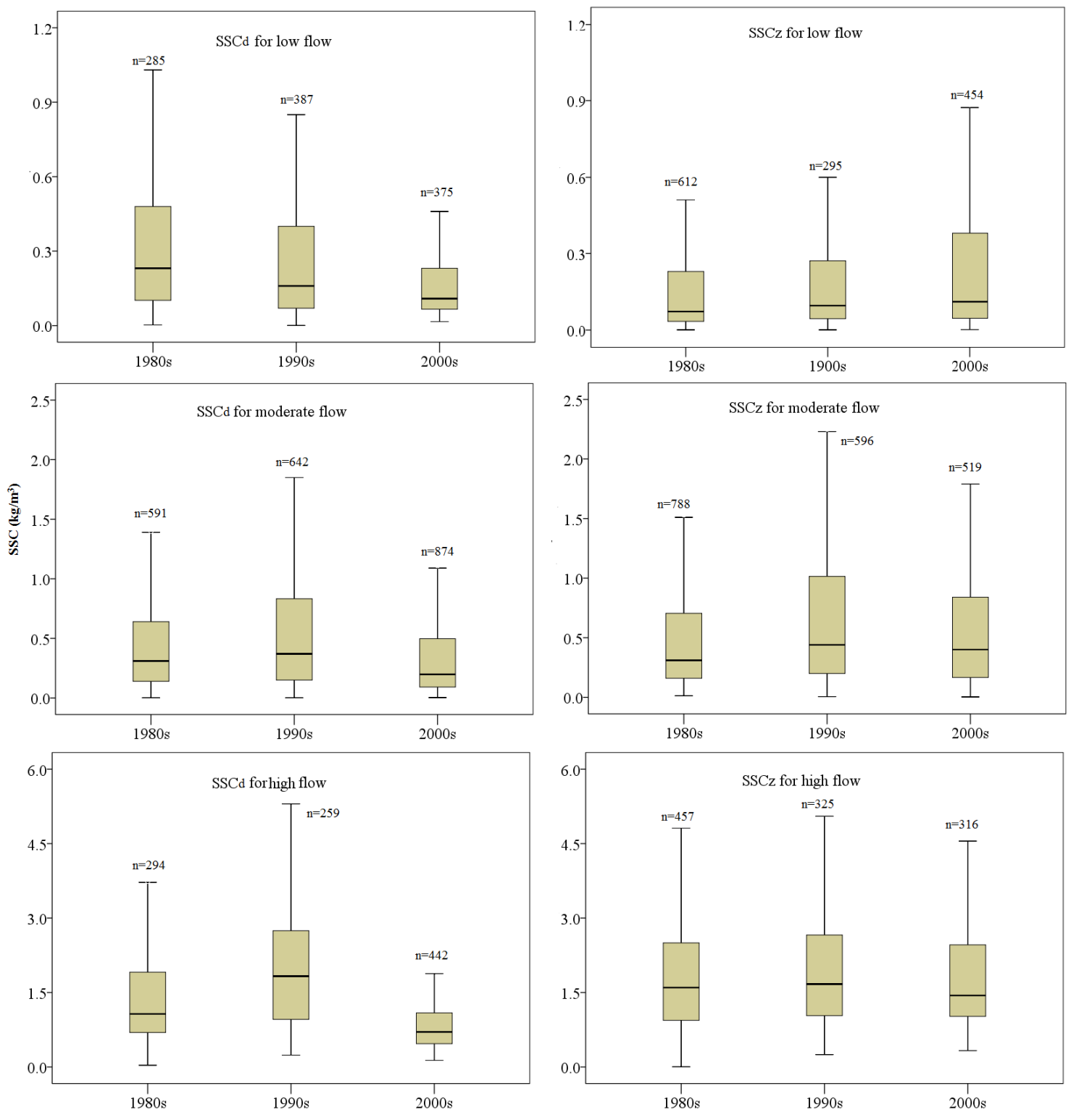

Figure 8. Box plots of SSC.

catchment. The increase in Qx was larger than the increase in Qd. The monitored sub-catchment covered approximately half of the entire catchment. Likewise, the combined mean annual discharge volume of the sub-catchment was nearly half of the total catchment output (i.e., a deficit of approximately $50 \%$ at the outlet). However, the SSC dynamics were more variable. Due to sediment delivery problems, sediment is generated on catchment slopes and is either stored on the surface or removed (Rankinen et al., 2010). Only a fraction of the gross soil erosion within a catchment will reach the outlet and be represented in the sediment yield. In addition, streamflow erodes the sediment directly from the surface or causes channel erosion, which removes the stored surface layer of detached sediment.
Our previous study in Du catchment showed that the area scale dominates the sediment delivery ratio (Shi et al., 2014). The sediment stored in the gullies is flushed to the river when a certain threshold is exceeded, and the deposition of sediment in channels is flushed at higher discharges. The max SSCx is greater than the max SSCd (31800 vs. $22400 \mathrm{~g} \mathrm{~m}^{-3}$ ). One possible explanation is that the sediment stock is depleted during a flood; this process does not occur simultaneously within the entire river basin and results in gradually decreasing SSCs downstream (Doomen et al., 2008). Cultivation or reforestation alters the slope surfaces but does not remove gullies and channels. The SSCs in Zhushan were only significantly different during high-flow 
and the reforestation period when the forest cover greatly increased.

\section{Conclusions}

This study investigated $Q$ and SSC dynamics for 30 years under cultivation and reforestation. The results of a MannKendall test showed that rainfall slightly increased during the study years; however, the annual discharge and sediment load significantly decreased. The sediment flux is extremely spatially and temporally variable. The relationship between SSC and $Q$ is complicated. Reforestation caused significant differences in the SSC for both low and moderate flows. For low and moderate flow, the changes in SSY primarily resulted from runoff, while the SSC showed little change. For the sub-catchment, the changes in the SSC were more sensitive to land use/cover changes. Meanwhile, cultivation resulted in significant differences in the SSC for high flow. Overall, our results provide useful information regarding SSC dynamics relative to land use/cover changes in mountainous catchments in a subtropical climate, which have largely been undocumented in the literature.

Acknowledgements. Financial support for this research was provided by the National Natural Science Foundation of China (41525003 and 41301294), and the Fundamental Research Funds for the Central Universities (2014YB053).

Edited by: M. Mikos

\section{References}

Aksoy, H. and Kavvas, M. L.: A review of hillslope and watershed scale erosion and sediment transport models, Catena, 64, 247271, doi:10.1016/j.catena.2005.08.008, 2005.

Bakker, M. M., Govers, G., van Doorn, A., Quetier, F., Chouvardas, D., and Rounsevell, M.: The response of soil erosion and sediment export to land-use change in four areas of Europe: The importance of landscape pattern, Geomorphology, 98, 213-226, doi:10.1016/j.geomorph.2006.12.027, 2008.

Borrelli, P., Marker, M., and Schutt, B.: Modelling Post-TreeHarvesting Soil Erosion and Sediment Deposition Potential in the Turano River Basin (Italian Central Apennine), Land Degrad. Dev., 26, 356-366, doi:10.1002/ldr.2214, 2015.

Buendia, C., Batalla, R. J., Sabater, S., Palau, A., and Marcé, R.: Runoff Trends Driven by Climate and Afforestation in a Pyrenean Basin, Land Degrad. Dev., doi:10.1002/ldr.2384, in press, 2015.

Casalí, J., Giménez, R., Díez, J., Álvarez-Mozos, J., Del Valle de Lersundi, J., Goñi, M., Campo, M. A., Chahor, Y., Gastesi, R., and López, J.: Sediment production and water quality of watersheds with contrasting land use in Navarre (Spain), Agr. Water Manage., 97, 1683-1694, doi:10.1016/j.agwat.2010.05.024, 2010 .
Cerdan, O., Govers, G., Le Bissonnais, Y., Van Oost, K., Poesen, J., Saby, N., Gobin, A., Vacca, A., Quinton, J., Auerswald, K., Klik, A., Kwaad, F. J. P. M., Raclot, D., Ionita, I., Rejman, J., Rousseva, S., Muxart, T., Roxo, M. J., and Dostal, T.: Rates and spatial variations of soil erosion in Europe: A study based on erosion plot data, Geomorphology, 122, 167-177, doi:10.1016/j.geomorph.2010.06.011, 2010.

Collins, A. L., Naden, P. S., Sear, D. A., Jones, J. I., Foster, I. D. L., and Morrow, K.: Sediment targets for informing river catchment management: international experience and prospects, Hydrol. Process., 25, 2112-2129, doi:10.1002/hyp.7965, 2011.

Cooper, J. A. G.: The role of extreme floods in estuary-coastal behaviour: contrasts between river- and tide-dominated microtidal estuaries, Sediment. Geol., 150, 123-137, doi:10.1016/S00370738(01)00271-8, 2002.

de Vente, J., Poesen, J., Verstraeten, G., Govers, G., Vanmaercke, M., Van Rompaey, A., Arabkhedri, M., and Boix-Fayos, C.: Predicting soil erosion and sediment yield at regional scales: Where do we stand?, Earth-Sci. Rev., 127, 16-29, doi:10.1016/j.earscirev.2013.08.014, 2013.

Doomen, A. M. C., Wijma, E., Zwolsman, J. J. G., and Middelkoop, H.: Predicting suspended sediment concentrations in the Meuse River using a supply-based rating curve, Hydrol. Process., 22, 1846-1856, doi:10.1002/hyp.6767, 2008.

Fang, N. F., Shi, Z. H., Li, L., Guo, Z. L., Liu, Q. J., and Ai, L.: The effects of rainfall regimes and land use changes on runoff and soil loss in a small mountainous watershed, Catena, 99, 1-8, doi:10.1016/j.catena.2012.07.004, 2012.

Francke, T., López-Tarazón, J. A., and Schröder, B.: Estimation of suspended sediment concentration and yield using linear models, random forests and quantile regression forests, Hydrol. Process., 22, 4892-4904, doi:10.1002/hyp.7110, 2008.

Gao, Z. L., Fu, Y. L., Li, Y. H., Liu, J. X., Chen, N., and Zhang, X. P.: Trends of streamflow, sediment load and their dynamic relation for the catchments in the middle reaches of the Yellow River over the past five decades, Hydrol. Earth Syst. Sci., 16, 3219-3231, doi:10.5194/hess-16-3219-2012, 2012.

García-Ruiz, J. M., Reguees, D., Alvera, B., Lana-Renault, N., Serrano-Muela, P., Nadal-Romero, E., Navas, A., Latron, J., Marti-Bono, C., and Arnaez, J.: Flood generation and sediment transport in experimental catchments affected by land use changes in the central Pyrenees, J. Hydrol., 356, 245-260, doi:10.1016/j.jhydrol.2008.04.013, 2008.

Gafur, A., Jensen, J. R., Borggaard, O. K., and Petersen, L.: Runoff and losses of soil and nutrients from small watersheds under shifting cultivation (Jhum) in the Chittagong Hill Tracts of Bangladesh, J. Hydrol., 274, 30-46, doi:10.1016/S00221694(03)00262-2, 2003.

Gocic, M. and Trajkovic, S.: Analysis of changes in meteorological variables using Mann-Kendall and Sen's slope estimator statistical tests in Serbia, Global Planet. Change, 100, 172-182, doi:10.1016/j.gloplacha.2012.10.014, 2013.

Harrington, S. T. and Harrington, J. R.: An assessment of the suspended sediment rating curve approach for load estimation on the Rivers Bandon and Owenabue, Ireland, Geomorphology, 185, 27-38, doi:10.1016/j.geomorph.2012.12.002, 2013.

Hopmans, P. and Bren, L. J.: Long-term changes in water quality and solute exports in headwater streams of intensively managed radiata pine and natural eucalypt forest catchments in 
south-eastern Australia, Forest Ecol. Manag., 253, 244-261, doi:10.1016/j.foreco.2007.07.027, 2007.

Ide, J. i., Kume, T., Wakiyama, Y., Higashi, N., Chiwa, M., and Otsuki, K.: Estimation of annual suspended sediment yield from a Japanese cypress (Chamaecyparis obtusa) plantation considering antecedent rainfalls, Forest Ecol. Manag., 257, 1955-1965, doi:10.1016/j.foreco.2009.02.011, 2009.

Izaurralde, R. C., Williams, J. R., Post, W. M., Thomson, A. M., McGill, W. B., Owens, L. B., and Lal, R.: Long-term modeling of soil $\mathrm{C}$ erosion and sequestration at the small watershed scale, Climatic Change, 80, 73-90, doi:10.1007/s10584-006-9167-6, 2007.

Kendall, M. G.: Rank correlation methods, Griffin, London, 1975.

Keesstra, S. D.: Impact of natural reforestation on floodplain sedimentation in the Dragonja basin, SW Slovenia, Earth Surf. Proc. Land., 32, 49-65, doi:10.1002/esp.1360, 2007.

Keesstra, S. D., van Dam, O., Verstraeten, G., and van Huissteden, J.: Changing sediment dynamics due to natural reforestation in the Dragonja catchment, SW Slovenia, Catena, 78, 60-71, doi:10.1016/j.catena.2009.02.021, 2009.

Khanchoul, K. and Jansson, M. B.: Sediment rating curves developed on stage and seasonal means in discharge classes for the Mellah wadi, Algeria, Geogr. Ann. A., 90, 227-236, doi:10.1111/j.1468-0459.2008.341.x, 2008.

Kisi, O., Karahan, M. E., and Şen, Z.: River suspended sediment modelling using a fuzzy logic approach, Hydrol. Process., 20, 4351-4362, doi:10.1002/hyp.6166, 2006.

Liébault, F., Gomez, B., Page, M., Marden, M., Peacock, D., Richard, D., and Trotter, C. M.: Land-use change, sediment production and channel response in upland regions, River Res. Appl., 21, 739-756, doi:10.1002/rra.880, 2005.

Liu, J. and Diamond, J.: China's environment in a globalizing world, Nature, 435, 1179-1186, doi:10.1038/4351179a, 2005.

Liu, Z., Yao, Z., Huang, H., Wu, S., and Liu, G.: Land Use and Climate Changes and Their Impacts on Runoff in the Yarlung Zangbo River Basin, China, Land Degrad. Dev., 25, 203-215, doi:10.1002/ldr.1159, 2014.

Liu, Q. J., Shi, Z. H., Fang, N. F., Zhu, H. D., and Ai, L.: Modeling the daily suspended sediment concentration in a hyperconcentrated river on the Loess Plateau, China, using the Wavelet-ANN approach, Geomorphology, 186, 181-190, doi:10.1016/j.geomorph.2013.01.012, 2013.

Lü, Y. H., Zhang, L. W., Feng, X. M., Zeng, Y., Fu, B. J., Yao, X. L., Li, J. R., and Wu, B. F.: Recent ecological transitions in China: greening, browning, and influential factors, Sci. Rep., 5, 8732, doi:10.1038/srep08732, 2015.

Luo, P. P., He, B., Chaffe, P. L. B., Nover, D., Takara, K., and Mohd Remy Rozainy, M. A. Z.: Statistical analysis and estimation of annual suspended sediments of major rivers in Japan, Environ. Sci. Proc. Imp., 15, 1052-1061, doi:10.1039/c3em30777h, 2013.

Mann, H. B.: Nonparametric Tests Against Trend, Econometrica, 13, 245-259, 1945.

Mizugaki, S., Onda, Y., Fukuyama, T., Koga, S., Asai, H., and Hiramatsu, S.: Estimation of suspended sediment sources using 137Cs and210Pbexin unmanaged Japanese cypress plantation watersheds in southern Japan, Hydrol. Process., 22, 4519-4531, doi:10.1002/hyp.7053, 2008.

Morehead, M. D., Syvitski, J. P., Hutton, E. W. H., and Peckham, S. D.: Modeling the temporal variability in the flux of sediment from ungauged river basins, Global Planet. Change, 39, 95-110, doi:10.1016/s0921-8181(03)00019-5, 2003.

Mount, N. J., Sambrook Smith, G. H., and Stott, T. A.: An assessment of the impact of upland afforestation on lowland river reaches: the Afon Trannon, mid-Wales, Geomorphology, 64, 255-269, doi:10.1016/j.geomorph.2004.07.003, 2005.

Naden, P. S. and Cooper, D. M.: Development of a sediment delivery model for application in large river basins, Hydrol. Process., 13, 1011-1034, 1999.

National Soil Survey Office: Soil survey technique in China: Agricultural Press, Beijing, 1992 (in Chinese).

Ni, J. R., Li, X. X., and Borthwick, A. G. L.: Soil erosion assessment based on minimum polygons in the Yellow River basin, China, Geomorphology, 93, 233-252, doi:10.1016/j.geomorph.2007.02.015, 2008.

Olang, L. O., Kundu, P. M., Ouma, G., and Furst, J.: Impacts of Land Cover Change Scenarios on Storm Runoff Generation: A Basis for Management of the Nyando Basin, Kenya, Land Degrad. Dev., 25, 267-277, doi:10.1002/ldr.2140, 2014.

Parsons, A. J., Cooper, J., and Wainwright, J.: What is suspended sediment?, Earth Surf. Proc. Land., 40, 1417-1420, doi:10.1002/esp.3730, 2015.

Rankinen, K., Thouvenot-Korppoo, M., Lazar, A., Lawrence, D. S. L., Butterfield, D., Veijalainen, N., Huttunen, I., and Lepistö, A.: Application of catchment scale sediment delivery model INCASed to four small study catchments in Finland, Catena, 83, 6475, doi:10.1016/j.catena.2010.07.005, 2010.

Renschler, C. S. and Harbor, J.: Soil erosion assessment tools from point to regional scales-the role of geomorphologists in land management research and implementation, Geomorphology, 47, 189-209, doi:10.1016/S0169-555x(02)00082-X, 2002.

Shi, Z. H., Cai, C. F., Ding, S. W., Wang, T. W., and Chow, T. L.: Soil conservation planning at the small watershed level using RUSLE with GIS: a case study in the Three Gorge Area of China, Catena, 55, 33-48, doi:10.1016/s0341-8162(03)00088-2, 2004.

Shi, Z. H., Huang, X. D., Ai, L., Fang, N. F., and Wu, G. L.: Quantitative analysis of factors controlling sediment yield in mountainous watersheds, Geomorphology, 226, 193-201, doi:10.1016/j.geomorph.2014.08.012, 2014.

Soil Survey Staff: Soil Taxonomy, A basic system of soil classification for making and interpreting soil surveys , 2nd Edn., Agricultural Handbook 436, Natural Resources Conservation Service, USDA, Washington DC, USA, 869 pp., 1999.

Stickler, C. M., Nepstad, D. C., Coe, M. T., McGrath, D. G., Rodrigues, H. O., Walker, W. S., Soares-Filho, B. S., and Davidson, E. A.: The potential ecological costs and cobenefits of REDD: a critical review and case study from the Amazon region, Global Change Biol., 15, 2803-2824, doi:10.1111/j.13652486.2009.02109.x, 2009.

Underwood, J. W., Renshaw, C. E., Magilligan, F. J., Dade, W. B., and Landis, J. D.: Joint isotopic mass balance: a novel approach to quantifying channel bed to channel margins sediment transfer during storm events, Earth Surf. Proc. Land., 40, 1563-1573, doi:10.1002/esp.3734, 2015.

Van Rompaey, A. J. J., Govers, G., and Puttemans, C.: Modelling land use changes and their impact on soil erosion and sediment supply to rivers, Earth Surf. Proc. Land., 27, 481-494, doi:10.1002/esp.335, 2002. 
Verbist, B., Poesen, J., van Noordwijk, M., Widianto, Suprayogo, D., Agus, F., and Deckers, J.: Factors affecting soil loss at plot scale and sediment yield at catchment scale in a tropical volcanic agroforestry landscape, Catena, 80, 34-46, doi:10.1016/j.catena.2009.08.007, 2010.

Walling, D. E.: Assessing the accuracy of suspended sediment rating curves for a small basin, Water Resour. Res., 13, 531-538, 1977.

Warrick, J. A., Madej, M. A., Goni, M. A., and Wheatcroft, R. A.: Trends in the suspended-sediment yields of coastal rivers of northern California, 1955-2010, J. Hydrol., 489, 108-123, doi:10.1016/j.jhydrol.2013.02.041, 2013.

Wei, W., Chen, L. D., Zhang, H. D., and Chen, J.: Effect of rainfall variation and landscape change on runoff and sediment yield from a loess hilly catchment in China, Environ. Earth Sci., 73, 1005-1016, doi:10.1007/s12665-014-3451-y, 2015.
Zhang, F., Tiyip, T., Feng, Z. D., Kung, H. T., Johnson, V. C., Ding, J. L., Tashpolat, N., Sawut, M., and Gui, D. W.: Spatio-Temporal Patterns of Land Use/Cover Changes over the Past 20 Years in the Middle Reaches of the Tarim River, Xinjiang, China, Land Degrad. Dev., 26, 284-299, doi:10.1002/ldr.2206, 2015.

Zhu, J. L., Gao, P., Geissen, V., Maroulis, J., Ritsema, C. J., Mu, X. M., and Zhao, G.-J.: Impacts of Rainfall and Land Use on Sediment Regime in a Semi-Arid Region: Case Study of the Wuqi Catchment in the Upper Beiluo River Basin, China, Arid Land Res. Manag., 29, 1-16, doi:10.1080/15324982.2014.919041, 2015. 